\title{
APPROPRIATENESS OF TWO INVENTORIES MEASURING INTUITION (THE PID AND THE REI) FOR SLOVAK POPULATION
}

\author{
Eva BALLOVÁ MIKUŠKOVÁ, Róbert HANÁK, Vladimíra ČAVOJOVÁ \\ Institute of Experimental Psychology, Slovak Academy of Sciences \\ Dúbravská cesta 9,84104 Bratislava, Slovak Republic \\ E-mail: expsebal@savba.sk
}

\begin{abstract}
There are several available measures that can help us to distinguish between two general types of processing, usually known as intuitive and deliberative. In the current study we examined two of them, Rationality-Experiantility Inventory and Preference for Intuition/Deliberation Scale in Slovak sample of 860 working adults and students (Study 1). In Study 2 (with $\mathrm{N}=428$ participants) we verified the 2-factor structure of REI after rephrasing problematic items shown in Study 1. The results showed that both PID and REI have good internal consistency, structures of Slovak versions correspond with the original versions. We found also some gender and age differences, and identified three factors (decision-making based on affect and holistic processing, decision-making based on creativity and cognitions, and planned, deliberate decision-making).
\end{abstract}

Key words: intuition, REI, PID, psychometric properties

Individual differences in decision-making have become increasingly important in decision-making literature (Stanovich, 2011), because they have consequences for our choices and rationality. Reliable assessment of these differences in cognitive styles used in decision-making is a challenge for researchers. On one hand, there are enough measures of various cognitive styles distinguishing between processes generally falling under Type 1 and Type 2 in a dual pro-

Acknowledgement

This work was supported by the Slovak Research and Development Agency under the contract No. APVV-0361-12. The authors wish to thank the anonymous reviewer for constructive suggestions in the process of improving our manuscript, but mostly our thanks go to the Institute of Experimental Psychology for providing an insightful workplace and many discussions regarding this manuscript. cess framework. On the other hand, most of these measures have several shortcomings - they are generally self-reported (therefore, it is necessary to establish their psychometric properties and construct validity on a larger sample), and most of them originated in Western cultures (therefore, it is necessary to examine their cross-cultural stability for use in countries outside their origin).

Within decision-making research, two broad basic preferences are distinguished: intuitive and deliberative, which is rooted in the dual process theories (Betsch \& Kunz, 2008; Gigerenzer, 2008; Gladwell, 2005; Kahneman, 2011; Sadler-Smith, 2008; Stanovich \& West, 2000; Stanovich, 2011; Westcott, 1961). Individuals differ in the degree they use intuition (Type 1 processes) and deliberation (Type 2 processes) in perception, thinking and solving problems. Based on this assumption, constructs of

DOI: $10.21909 / \mathrm{sp} .2015 .01 .674$ 
cognitive styles have been formulated and, subsequently, various scales measuring these constructs have been created to identify the degree to which an individual relies on intuitive or deliberative problem solving and decision-making. On the other hand, there are some arguments against identification of intuition with Type 1 processes and deliberation with Type 2 processes (Čavojová \& Hanák, 2014). Cultural studies reviewed by Buchtel and Norenzayan (2009) suggest that holistic processing can also be learned, effortful and normatively correct for solving some problems, and that it is likely to reflect cultural differences in Type 2 processing. Evans and Stanovich (2013) distinguish between types (Type 1 and 2 as qualitatively distinct ways of processing information) and modes of processing, which are cognitive styles and are manifest within the domain of what is regarded as Type 2 thinking. Taking cognitive styles as only a variation in the domain of Type 2 processes largely explains the many cultural differences reviewed by Buchtel and Norenzayan (2009).

The increase of research interest in intuition in decision making has been accompanied by an increase of methods measuring this construct. Intuition can be measured within a dual process theories framework as an (in)ability to suppress an intuitive (yet incorrect) answer (Frederick, 2005), or as a preferred cognitive style or personality dimension (e.g., Betsch, 2004; Myers Briggs, McCaulley, Quenk, \& Hammer, 1998; Pacini \& Epstein, 1999). We focused on the two most widely used measures, the Preference for Intuition/Deliberation scale PID (Betsch, 2004) and the Rational-Experiential Inventory REI (Pacini \& Epstein, 1999) and we examine analytical/deliberative and intuitive/experiential cognitive styles as two modes of pro- cessing information within the Type 2 processes.

\section{Aim and Rationale of the Study}

The purpose of the present study was to find out which of the two inventories measuring intuitive and rational thinking is more appropriate to further research on intuition and rationality. The first aim was to establish usability of the PID and the REI in Slovak population by verifying their psychometric parameters, confirming their structure, and exploring the gender and age differences. The second aim was to examine the validity of the PID and the REI in Slovak population by correlating it with another instrument measuring cognitive styles, and by looking for underlying factors.

Our expectations were based on the results of previous studies using both PID and REI. Original authors of both PID and REI provided evidence for good internal consistency of their scales (review in Table 2) and we expected good internal consistency in our sample as well, despite its different cultural background. Next, although two-factor structure of PID seemed to be well grounded (Betsch, 2005; Richetin, Perugini, Adjali \& Hurling, 2007), studies regarding REI are not so conclusive (Björklund \& Bäckström, 2008; Pretz \& Totz, 2007). We expected that the original two factor structure of the PID and two-factor (and four dimensions) structure of the REI would be replicated in the Slovak sample.

Although several studies (Epstein, 2003; Sladek, Bond, \& Phillips, 2010) suggest higher self-reported preference for rationality in men, there is as yet no consensus regarding the stereotype of "women's intuition". On the one hand, women tend to score 
higher than men on several measures regarding constructs related to dominant gender stereotypes, such non-verbal communication (Lieberman, 2000; Myers, 2002), empathy, orientation on relationship (Myers, 2002), and theory of mind (Čavojová, Belovičová, $\&$ Sirota, 2011). On the other hand, there is a lack of evidence in other studies (e.g., Hayes, Allinson, \& Armstrong, 2004; Hodgkinson \& Sadler-Smith, 2003) confirming the stereotype that women are more intuitive than men.

Furthermore, we examined whether there are any age differences in preferences for intuition/experientiality and deliberation/rationality. Based on the results of Sladek, Bond and Phillips (2010), we expected to confirm that with increasing age, preference for the experiential system decreases (because of cognitive maturity). However, the authors also found decreasing preference for rational system, and thus recommend further study in this area.

Our secondary aim was to determine whether there is an overlap between various instruments measuring intuition and deliberation, whether they measure the same construct or whether they measure various aspects of intuition and deliberation. Several other studies suggest that by using various scales, we can identify more underlying factors behind decision-making, such as: 1) decision making based on affect, 2) decision making based on cognitions, 3) planned, structured decision making, and 4) automatic, spontaneous decision making (Betsch \& Iannello, 2010). Therefore, we also expected to find more than two factors using three different scales for measuring intuitive and deliberative decision-making.

To summarize, we present an extensive study of two most widely used measures distinguishing between deliberative and intui- tive modes of thinking and decision-making and an attempt to look for an underlying factor structure; the endeavor which is novel in Slovakia and which can contribute to the general use of both measures in Slovakia and abroad.

\section{STUDY 1}

\section{EXPLORINGTHEPSYCHOMETRIC PARAMETERS OF THE PID AND THE REI}

In Study 1 (a) the internal consistency of both PID and REI scales and the structure of PID and REI were verified, (b) gender and age differences were explored and (c) a possible overlap or the lack thereof between selfreported scales in measuring intuition and deliberation was determined.

\section{Methods}

\section{Participants}

The study sample consisted of 860 adult participants from the Slovak Republic (68\% women), who were full-time students of the Economic University in Bratislava and parttime students of the College of Economy and Management of Public Service in Bratislava (employed in administrative, economic and managerial positions). Age of participants ranged from 18 to $66(\mathrm{M}=27.68$; $\mathrm{SD}=8.07)$.

\section{Procedure}

We administered the PID (Betsch, 2004) to 750 Slovak participants, the REI (Pacini \& Epstein, 1999) to 628 participants, and the CoSI (Cools \& Van den Broeck, 2007) 
to 395 participants. Participants were recruited by emails to complete the REI, the PID, the CoSI as well as some other measures not reported here. All instruments were administered online via GoogleDoc forms. Students received course credit for their participation.

\section{Materials}

\section{Preference for Intuition and Deliberation (PID)}

Preference for Intuition and Deliberation (PID; Betsch, 2004) scale is an instrument for measuring affective intuition (defined as being based on implicit knowledge and also as a basic mode of decision-making, which uses affect as a decision criterion). Deliberation is defined as decision-making using explicit evaluation, rules of deciding, beliefs and reasons. According to Betsch, intuition and deliberation in PID represent two separate dimensions not two ends of one bipolar dimension. PID consists of 18 items; 9 for PID-Intuition (e.g., "I listen carefully to my deepest feelings.") and 9 for PID-Deliberation (e.g., "Before making decisions I usually think about the goals I want to achieve."). Participants indicate their agreement with these statements on a 5-point Likert scale with 1 meaning "totally disagree" to 5 "totally agree".

\section{Rational-Experiential Inventory (REI)}

REI is based on Cognitive-Experiential SelfTheory (e.g., Epstein, 2003) and consists of two formerly separate scales - Need for Cognition (basis for Rationality scale) and Faith in Intuition (basis for Experientiality scale). Epstein developed several versions of REI.
In this study we used the version by Pacini and Epstein (1999), which measures two thinking styles and includes four dimensions: Rational engagement and Rational ability (together they form the Rational thinking style, 20 items), and Experiential engagement and Experiential ability (together they form the Experiential thinking style, 20 items). In the original REI, the items were evaluated on a 5-point Likert scale. In the Slovak version, Sirota (2008) replaced the original 5-point scale with a 6-point scale to eliminate central tendency. We also used a 6-point scale to indicate agreements with REI items (1 meaning "totally disagree" to 6 "totally agree").

\section{Cognitive Style Indicator (CoSI)}

CoSI (Cools \& Van den Broeck, 2007) is an 18 item questionnaire measuring three cognitive styles: people's preferences for perception, processing, and structuring of information. Items are scored on a 5-point scale, with 1 meaning "totally disagree" to 5 "totally agree". Authors distinguish three cognitive styles: Knowing, Planning, and Creating. The Knowing style is defined within CoSI as an emphasis on logic, precision and objectivity, which makes it similar to more traditional scales measuring rational/deliberative cognitive style. Planning emphasizes structure, control and routine, while Creating emphasizes subjectivity, impulsivity and openness to possibilities. Although no subscale measures intuition explicitly, CoSI was used in a validation study by Betsch and Iannello (2010) and we included it to check whether a different conceptualization of cognitive style (not based on a dual process approach) would add new aspects to the concept of the deliberation/intuition division. 


\section{Results}

In Table 1 we present descriptive statistics of used subscales of individual measures (range of scores, median, mean, standard deviation). Distribution of data in our sample was normal; therefore, we used parametric statistical methods in all subsequent analyses.

\section{Basic Psychometric Parameters}

\section{Reliability of PID and REI}

The internal consistency of PID in the Slovak sample was .827 for Deliberation and .738 for Intuition, measured by Cronbach's alpha (Table 2). However, removing item 9 "I like emotional situations, discussions, and movies" increased Cronbach's alpha for Intuition to .756. The internal consistency of REI was .861 for Rational thinking style and .872 for
Experiential thinking style (results for dimensions are reported in Table 2). Removing item 9 "My snap judgments are probably not as good as most people's" from the Experiential ability dimension increased Cronbach's alpha for this dimension to .886 .

A comparison of our results for both scales with other studies is also shown in Table 2.

Confirmation of the structure of PID and REI

To examine the structure of the PID and the REI, confirmatory factor analysis was used. We tested two models for PID ( $\mathrm{n}=$ 872): The two-factor model (PID Model 2) was compared with a one-factor model (PID Model 1). More detailed results and descriptions are in Table 3 . In general the one-factor model showed poor fit $\left(\chi^{2}(135)=1567.07\right.$; $\mathrm{p}<.001$; $\mathrm{RMSEA}=.110 ; \mathrm{CFI}=.616)$. The two-factor model (PID Model 2), with intuition and deliberation as separate factors,

Table 1 Descriptive statistics for PID, REI, CoSI

\begin{tabular}{lccccc}
\hline & $N$ & $\mathrm{R}$ & $\mathrm{Mdn}$ & $M$ & $S D$ \\
\hline PID - intuition & 750 & $15-45$ & 31 & 30.59 & 5.03 \\
PID - deliberation & & $9-45$ & 35 & 34.28 & 5.85 \\
& & & & \\
REI - rational thinking style & & $34-114$ & 81 & 80.65 & 13.38 \\
$\quad$ REI - rat. engagement & & $20-58$ & 40 & 39.76 & 6.87 \\
$\quad$ REI - rat. ability & 628 & $14-58$ & 41 & 40.90 & 7.85 \\
REI - experiential thinking & & & 75 & 75.63 & 14.03 \\
style & & $16-60$ & 37 & 37.35 & 8.20 \\
$\quad$ REI - exp. engagement & & & & & \\
$\quad$ REI - exp. ability & & $5-20$ & 17 & 14.85 & 2.79 \\
& 395 & $12-35$ & 28 & 27.46 & 4.33 \\
CoSI - knowing & & $10-35$ & 26 & 25.92 & 4.57 \\
CoSI - planning & & & & \\
CoSI - creativity & & & & & \\
\hline
\end{tabular}

Note. $\mathrm{R}$ - range, $\mathrm{Mdn}$ - median, $\mathrm{M}$ - mean, $\mathrm{SD}$ - standard deviation 
Table 2 Internal consistency of PID and REI measured by Cronbach's alpha, comparison with other researches

\begin{tabular}{|c|c|c|c|c|c|c|c|c|c|}
\hline \multirow[b]{3}{*}{ our results* } & \multirow{2}{*}{$\mathbf{N}$} & \multicolumn{2}{|c|}{ PID } & \multicolumn{6}{|c|}{ REI } \\
\hline & & $\mathrm{D}$ & I & $\mathrm{R}$ & RA & $\mathrm{RE}$ & $\mathrm{E}$ & EA & $\mathrm{EE}$ \\
\hline & $\begin{array}{l}750^{\text {a) }} \\
628^{\text {b) }}\end{array}$ & .827 & .738 & .861 & .817 & .728 & .872 & .738 & .821 \\
\hline Betsch, 2004, & 2132 & .79 & .77 & & & & & & \\
\hline Richetin et al., 2007 & 299 & .77 & .62 & & & & & & \\
\hline Witteman et al., 2009 & $\begin{array}{l}405^{\mathrm{a})} \\
774^{\mathrm{b})}\end{array}$ & .85 & .87 & .86 & & & .91 & & \\
\hline Pacini \& Epstein, 1999 & 399 & & & .90 & .83 & .84 & .87 & .80 & .79 \\
\hline $\begin{array}{l}\text { Björklund \& } \\
\text { Bäckström, } 2008\end{array}$ & 203 & & & .86 & .81 & .78 & .88 & .79 & .84 \\
\hline $\begin{array}{l}\text { Jurišová \& Pilárik, } \\
\text { 2012* }\end{array}$ & 424 & & & .86 & .77 & .81 & .85 & .75 & .77 \\
\hline Sirota, 2008* & 151 & & & & .77 & .79 & & .81 & .79 \\
\hline
\end{tabular}

Note. * Slovak samples; ${ }^{\text {a) }}$ for PID, ${ }^{\text {b) }}$ for REI

D - Deliberation (PID), I - Intuition (PID), R - Rational thinking style (REI), RA - Rational ability (REI), RE - Rational engagement (REI), E - Experiential thinking style (REI), EA - Experiential ability (REI), EE - Experiential engagement (REI)

$\mathrm{a}$ - participants for PID study, b - participants for REI study

Table 3 Chi-square values, degrees of freedom, $p$-values and fit indices for the different models of PID and REI

\begin{tabular}{|c|c|c|c|c|c|c|c|c|c|c|c|c|}
\hline & Model & $\chi^{2}$ & $\mathrm{df}$ & $\mathrm{p}$ & RMSEA & CI 90\% & PCLOSE & GFI & CFI & NFI & PGFI & AIC \\
\hline \multirow{2}{*}{ 忩 } & Model 1 & 1567.07 & 135 & $<0.001$ & .110 & $.105-.115$ & .000 & .75 & .62 & .60 & .59 & 1.88 \\
\hline & Model 2 & 647.98 & 134 & $<0.001$ & .066 & $.061-.072$ & .000 & .92 & .86 & .83 & .72 & .870 \\
\hline \multirow{3}{*}{ 㱏 } & Model 1 & 6561.52 & 702 & $<0.001$ & .105 & .103 & .000 & .5 & .41 & .39 & .46 & 8.90 \\
\hline & Model 2 & 3685.21 & 739 & $<0.001$ & .073 & $.070-.075$ & .000 & .74 & .71 & .66 & .67 & 5.10 \\
\hline & Model 3 & 3401.21 & 734 & $<0.001$ & .069 & $.067-.072$ & .000 & .75 & .74 & .69 & .67 & 4.73 \\
\hline
\end{tabular}

Note. $\mathrm{N}=203$. RMSEA - root mean square error of approximation, GFI - goodness of fit index, CFI Bentler's comparative fit index, NFI - Bentler's normed fit index, PGFI - parsimony goodness of fit index, ECVI - expected cross-validation index 
shows an acceptable level of fit $\left(\chi^{2}(134)=\right.$ 647.98; $\mathrm{p}<.001 ; \mathrm{RMSEA}=.066 ; \mathrm{CFI}=.862)$.

For the REI, three models were tested $(\mathrm{n}=$ 756): a one factor model (REI Model 1), a two-factor model with one factor for rationality and one factor for experientiality (REI Model 2) and a four-factor model with two correlated factors for rationality (REI-RF, REIRA) and two correlated factors for experientiality (REI-EF, REI-EA; REI Model 3). Detailed results are in Table 3. The one- and two-factor models showed poor fit. The fourfactor model gave the best results $\left(\chi^{2}(734)=\right.$ $3401.21 ; \mathrm{p}<.001 ; \mathrm{RMSEA}=.069 ; \mathrm{CFI}=.740)$, therefore, in further analyses we report results for the four dimensions of REI.

\section{Gender Differences}

We found statistically significant differences, but with small effect size, between men and women in PID Intuition $(\mathrm{p}<.001 ; \mathrm{t}=$ $4.350 ; \mathrm{d}=.340 ; 95 \%$ CI [-2.47, -.93]), with women seeing themselves as more intuitive in comparison with men. We did not find any statistically significant differences between men and women in PID Deliberation (for more details see Table 4).

We found statistically significant gender differences with moderate and small effect size in REI in both thinking styles (for Rational thinking style $\mathrm{p}<.001 ; \mathrm{t}=6.248 ; \mathrm{d}=$ $.550 ; 95 \%$ CI [4.88, 9.37]; for Experiential thinking style $\mathrm{p}=.002 ; \mathrm{t}=3.125 ; \mathrm{d}=.270$; $95 \%$ CI $[-6.20,-1.41])$, and in all four dimensions (Table 4). Men reported that they preferred more Rational thinking style than women and women reported that they preferred more Experiential thinking style, in comparison with men.

\section{Effect of Age}

Age of participants ranged from 18 to 68 and the correlation of the PID, the REI and age was examined. Age positively correlated

Table 4 Gender differences in PID and REI

\begin{tabular}{lrrrrrrr}
\hline & \multicolumn{2}{c}{ men } & \multicolumn{2}{c}{ women } & \multicolumn{3}{c}{ gender differences } \\
& \multicolumn{1}{c}{$M$} & \multicolumn{1}{c}{$S D$} & $M$ & $S D$ & $t$ & \multicolumn{1}{c}{$p$} & $d$ \\
\cline { 2 - 8 } & & & & & & & \\
PID-I & 29.42 & 5.00 & 31.12 & 4.96 & -4.350 & $<.001$ & .340 \\
PID-D & 34.51 & 6.18 & 34.18 & 5.70 & .720 & .471 & .060 \\
& & & & & & & \\
REI-R & 85.70 & 13.01 & 78.57 & 12.98 & 6.248 & $<.001$ & .550 \\
REI-RA & 41.13 & 7.11 & 39.20 & 6.69 & 7.787 & $<.001$ & .680 \\
REI-RE & 44.51 & 7.07 & 39.40 & 7.68 & 3.214 & $\mathbf{. 0 0 1}$ & .280 \\
REI-E & 72.94 & 13.75 & 76.74 & 14.01 & -3.125 & $\mathbf{. 0 0 2}$ & .270 \\
REI-EA & 37.12 & 6.66 & 38.76 & 7.04 & -2.695 & $\mathbf{. 0 0 7}$ & .240 \\
REI-EE & 35.81 & 8.09 & 37.98 & 8.16 & -3.054 & $\mathbf{. 0 0 2}$ & .270 \\
\hline
\end{tabular}

Note. PID-D - Deliberation, PID-I - Intuition, REI-R - Rational thinking style, REI-RA - Rational ability, REI-RE - Rational engagement, REI-E - Experiential thinking style, REI-EA - Experiential ability, REI-EE - Experiential engagement 
with PID Deliberation $(\mathrm{r}=.193, \mathrm{p}<.001)$, REI Rational thinking style $(r=.203, p<.001)$ and also with REI dimensions Rational ability $(\mathrm{r}=.173, \mathrm{p}<.001)$ and Rational engagement $(\mathrm{r}=.192, \mathrm{p}<.001)$. Correlations are low (explaining $2.99 \%-4.12 \%$ of variability), so further examination is needed to eliminate the possibility that the results occurred due to error variance. (For more details see Figures 1 and 2 in Appendix A). We found no correlation between age and Intuition in the PID and Experiential thinking style (and its dimensions).

\section{Looking for an Underlying Factor}

We examined a mutual overlap between the PID, the REI, and the CoSI and the extent to which they map similar aspects of intuition and deliberation. We transformed the scores of all subscales into standardized z-scores and subjected them to exploratory factor analysis (principal component, varimax rotation). All four REI dimensions of thinking styles were included. Based on visual inspection of the scree plot and observed Eigen- values, a three-factor solution was extracted (Bartlett's test of sphericity, $\chi^{2}(36)=1186.60$, $\mathrm{p}<.001 ; \mathrm{KMO}=.705)$. The first factor accounted for $26.78 \%$ of the total variance (Eigenvalue $(\lambda)=2.83$ ) and included items concerning Intuition (PID), Experiential ability (REI), and Experiential engagement (REI) and we labelled it as "decision-making based on intuition and experientiality". Second factor accounted for $23.90 \%$ of the total variance (Eigenvalue $(\lambda)=2.40$ ) and included Rational ability (REI), Rational engagement (REI), and Creativity (CoSI) and we labelled it as "decision-making based on creativity and cognitions". Finally, the third factor $(\lambda=$ $1.06 ; 19.29 \%$ of variance) consisted of Planning (CoSI ), Knowing (CoSI ) and Deliberation (PID) and we labelled it as "planned, deliberated decision-making" (for more details see Table 5).

\section{Summary of Results}

The results of Study 1 can be summarized as follows: (1) both PID and REI have good internal consistency (above .7);

Table 5 Factor analysis of PID, REI, and CoSI

\begin{tabular}{lccc}
\hline & $\begin{array}{c}\text { "decision-making } \\
\text { based on intuition and } \\
\text { experientiality“ }\end{array}$ & $\begin{array}{c}\text { "decision-making } \\
\text { based on creativity } \\
\text { and cognitions“ }\end{array}$ & $\begin{array}{c}\text { „planned, } \\
\text { deliberated } \\
\text { decision-making“ }\end{array}$ \\
\hline experiential ability (REI) & $\mathbf{. 8 9 1}$ & -.034 & -.157 \\
experiential engagement (REI) & $\mathbf{. 8 6 6}$ & .061 & .033 \\
intuition (PID) & $\mathbf{. 8 4 8}$ & -.011 & .170 \\
rational ability (REI) & -.035 & $\mathbf{. 8 4 6}$ & .133 \\
rational engagement (REI) & -.160 & $\mathbf{. 8 1 7}$ & .195 \\
creating (CoSI) & .291 & $\mathbf{. 6 2 4}$ & .065 \\
planning (CoSI) & -.066 & .040 & $\mathbf{. 8 7 8}$ \\
deliberation (PID) & .166 & .248 & $\mathbf{. 7 1 3}$ \\
knowing (CoSI) & -.068 & .557 & $\mathbf{. 5 8 6}$ \\
\hline
\end{tabular}


(2) two-factor structure for the Slovak version was confirmed; (3) four-factor structure of the Slovak version of the REI was verified; (4) there were only marginal differences between men and women in their preference for intuitive and deliberation, which can reflect more internalized cultural stereotypes than any real difference in using intuition/deliberation; and (5) there is tendency that with increasing age self-reported preference for Deliberation and Rational thinking style of participants increase, but due to small effect sizes, the interpretation can be similar as with gender differences and further examination with more age-diverse sample is needed.

Most importantly, we tried to establish whether scales measuring intuition map the same construct or several aspects of intuition. We identified three factors (decisionmaking based on affect and holistic processing, decision-making based on creativity and cognitions, and planned, deliberate decisionmaking). This indicates good differentiation of the scales, but all subscales concerning intuition loaded only to one factor.

To summarize, the PID shows good internal consistency and we verified the twofactor structure of the PID, but its scales are correlated (.29). It suggests that PID does not distinguish between deliberative and intuitive decision style as well as REI and its usability in further research is questioned. The REI, on the other hand, has good internal consistency, but the confirmatory factor analysis showed some unclear findings concerning the structure of the REI. Similar results were also obtained by Björklund and Bäckström (2008), who subsequently supported four dimensions of REI by means of confirmatory factor analysis. In the next study, therefore, we con- centrate on reducing the flaws that the current study showed - namely, the problematic formulation of item 9 of the Experiential ability that reduced internal consistency of the subscale and the confirmatory factor analysis on new data to verify the four factor model of the REI.

STUDY 2

\section{REVISIONAND CONFIRMATIONOF THE RATIONAL-EXPERIENTIAL INVENTORY}

In Study 2 (a) the internal consistency and the structure of the REI after reformulating item 9 of the Experiential ability dimension were examined by means of confirmatory factor analysis and (b) gender and age differences were explored and compared to Study 1.

\section{Methods}

\section{Participants}

The study sample consisted of 428 students from the Slovak Republic $(86.5 \%$ female), who were full-time students at the Pedagogical faculty of Constantine the Philosopher University in Nitra (future teachers). Age of participants ranged from 18 to $26(\mathrm{M}=$ 19.67; $\mathrm{SD}=1.11$ ).

\section{Procedure}

Participants were recruited by emails to complete the REI as well as some other measures not reported here. All instruments were administered online via www.survio.com. Students received course credit for their participation. 
Table 6 Descriptive statistics for REI

\begin{tabular}{lccccr}
\hline & $N$ & $R$ & $M d n$ & $M$ & \multicolumn{1}{c}{$S D$} \\
\hline REI - rational thinking style & & $34-110$ & 70 & 70.46 & 12.65 \\
REI - rat. engagement & & $14-55$ & 35 & 34.97 & 7.19 \\
REI - rat. ability & \multirow{2}{*}{428} & $15-55$ & 35 & 35.49 & 6.92 \\
REI - experiential thinking style & & $32-114$ & 74 & 75.31 & 12.26 \\
REI - exp. engagement & & $16-55$ & 37 & 37.69 & 6.56 \\
REI - exp. ability & & $11-59$ & 37 & 37.62 & 7.03 \\
\hline
\end{tabular}

Note. $\mathrm{R}$ - range, Mdn - median, $\mathrm{M}$ - mean, $\mathrm{SD}$ - standard deviation

\section{Material}

Rational-Experiential Inventory (REI)

For detail description of the REI see Study 1, except in the Study 2 one correction in the REI was made in item 9 ("My snap judgments are probably not as good as most people's."). It was done because the reliability analysis in the previous study revealed that this item is difficult to understand for participants (because of the negative formulation and reverse scoring) and in this study we tested, whether the new formulation would increase internal consistency of the subscale.

\section{Results}

\section{Descriptive Statistics}

Descriptive statistics (mean, standard deviation, Cronbach's alpha, inter-subscale correlations) from the REI are presented in Table 6. The internal consistency of the thinking styles subscales measured by Cronbach's alpha coefficients was satisfactory (.806 for rational thinking style and .803 for experiential thinking style). On the other hand, reliability of the dimensions ranged only from .651 to .723 .

\section{Confirmatory Factor Analysis}

Two models were tested for REI $(n=428)$ : a two-factor and four-factor model. For improving model fit we covariated some specific items in all models. The first model was a two-factor model (Model 4) and this model had the highest theoretical credibility (Björklund \& Bäckström, 2008). This model included one factor for rationality and one factor for experientiality; $\chi^{2}(739)=2070,1$; $\mathrm{p}<.001 ; \mathrm{RMSEA}=.072 ; \mathrm{CFI}=.616$. Model 5 was a four-factor model with two correlated factors for rationality (REI-RF, REI-RA) and two correlated factors for experientiality (REIEF, REI-EA); $\chi^{2}(740)=2867,9 ; p<.001$; $\mathrm{RMSEA}=.082 ; \mathrm{CFI}=.499$. For more details consult Table 7 . The model fit of both models was far from optimal and results favored no model.

Confirmatory factor analysis showed that there are some problematic items in REI: they had low factor loading and high levels of between items covariance. Specifically, these were the items 8 from Rational engagement and 9 from Experiential engagement and items 8 and item 10 from Experiential ability. ${ }^{1}$ After

\footnotetext{
${ }^{1}$ Labelling of items is the same as in the study of Pacini and Epstein (1999).
} 
Table 7 Confirmatory factor analysis for REI

\begin{tabular}{ccccccccccccc}
\hline Model & $\chi^{2}$ & $d f$ & $p$ & RMSEA & CI 90\% & PCLOSE & GFI & CFI & NFI & PGFI & ECVI & AIC \\
\hline $\mathrm{n}=428$ & & & & & & & & & & & & \\
Model 4 & 2070.1 & 739 & $<.001$ & .072 & $.069-.075$ & .000 & .736 & .616 & .528 & .663 & 5.930 & 2531.1 \\
Model 5 & 2867.9 & 740 & $<.001$ & .082 & $.068-.075$ & .000 & .706 & .499 & .429 & .473 & 7.091 & 3027.9 \\
& & & & & & & & & & & & \\
Model 6 & 1971.6 & 593 & $<.001$ & .074 & $.070-.077$ & .000 & .759 & .652 & .571 & .676 & 4.959 & 2117.6 \\
Mode1 7 & 1920.1 & 588 & $<.001$ & .073 & $.069-.076$ & .000 & .759 & .664 & .582 & .670 & 4.862 & 2076.1 \\
& & & & & & & & & & & & \\
Mode1 8 & 352.1 & 165 & $<.001$ & .052 & $.044-.059$ & .000 & .926 & .912 & .849 & .727 & 1.035 & 442.1 \\
Model 9 & 462.9 & 164 & $<.001$ & .065 & $.058-.072$ & .000 & .897 & .860 & .801 & .701 & 1.300 & 554.9 \\
\hline
\end{tabular}

exclusion of these items the confirmatory factor analysis for shortened REI was computed: again, two models were tested $(\mathrm{n}=$ 428): a two-factor (Model 6) and four-factor model (Model 7). However, again CFA did not provide strong support for either model and the parameters were not substantially better (for more detail see Table 7).

Moreover, the results of the last CFA (Model 6 and Model 7) suggested more possible items for exclusion (for factor loadings of items see Tables 1 and 2 in Appendix B). After reducing the REI by about half of the items (20 items, five for each dimension ${ }^{2}: 16$ from all 20 excluded items were similar to at least one remaining item, 3 excluded items were ambiguous, and one had too complicated a formulation) both two-factor (Model 8) and four-factor (Model 9) models with allowed covariance were tested to obtain the

\footnotetext{
${ }^{2}$ Items REI re1, re3, re4, re5, re7; ra2, ra3, ra4, ra6, ra9; ee1, ee2, ee3, ee4, ee5; ea2, ea3, ea5, ea6, ea9- labelling of items is the same as in the study of Pacini and Epstein (1999).
}

best model fit. As can be seen in Table 7 (Model 8,9), these models show satisfactory results as well as internal consistency (Cronbach's alpha for REI-R was .774 and for REI-E it was .817).

\section{Gender Differences and Effect of the Age}

Gender differences in Rational thinking style and Experiential thinking style were not found.

Age of participants ranged from 18 to 26 and the correlation of the REI and age was examined. As in Study 1, age positively correlated with rational thinking style $(r=.143$, $\mathrm{p}=.003)$ and also with dimension Rational ability $(\mathrm{r}=.107, \mathrm{p}=.028)$ and Rational engagement $(\mathrm{r}=.151, \mathrm{p}=.002)$, but again, correlations were low and explained only $1.14 \%-2.28 \%$ of the variability (for more details see Figure 3 in Appendix A), so the effect of age in this case was negligible. It was probably caused by our sample, which was not representative of age, thus further studies are needed to make conclusions about the effect of age. 


\section{Summary of Results}

The aim of Study 2 was to study internal consistency of REI and its factor structure as proposed in Study 1. The results showed somewhat weaker internal consistency than in Study 1 (Cronbach's alpha of Rational engagement and Experiential ability was less than .7), but these results may be due to a smaller sample.

Confirmatory factor analysis showed that there are some problematic items in the Slovak version of the REI. After exclusion of these items, internal consistency increased and ranged from .669 to .829 , but confirmatory factor analysis did not show any substantial improvement in either the two-factor or the four-factor model. The model improved only after a rather radical elimination of more than half of the items from the REI.

In contrast to the results of Study 1, in Study 2 no gender differences were found. It was probably caused by the fact that majority of participants in Study 2 were women. Similarly, the effect of age on preference of rational thinking style was only small and can reflect either internalized cultural stereotypes (older people should be more rational), but more probably, it was caused by our sample, which was not representative of age.

\section{General Discussion}

The results of both our studies showed that both scales - PID and REI - have a good internal consistency and our results are generally in accordance with other studies (Table 2; Betsch, 2004; Witteman et al., 2009, Epstein, 2003). On the other hand, we identified several problematic issues not mentioned by the original authors and we discuss these findings in the next paragraphs.

The problem with PID is that both of its scales correlate with each other (.29), despite the claim of the author (Betsch, 2004) that these are two independent dimensions. The biggest advantage of the PID is that it is relatively short and easy to administer, however, it seems not to distinguish between analytic/ deliberate and intuitive/experiential modes of thinking as well as the REI does. Relatively problematic is also the measuring of intuitive thinking styles by items tapping on affect (e.g., "I love emotional situation, discussion, and films" and "I prefer emotional people"). On the other hand, REI seems to be the more appropriate choice for distinguishing between analytic/rational and intuitive/experiential people, although we did not confirm the four-factor structure. Distinguishing between ability and engagement seems redundant. The bigger problem with REI is its length and relatively complicated phrasing of some of the items. Marks, Hine, Blore, and Philips (2008) also noted the difficulty of some items in REI, especially for adolescents, who were their participants, so they composed REI-A - Rational and experiential inventory for adolescents with 20 items. Not only Marks with colleagues, but also Norris, Pacini, and Epstein (1998) created a short form of REI consisting from 10 items. According to our results and similarity of some items, we also proposed a reduction of items in REI together with simplifying some formulations, and last but not least, verification of the REI-short version.

Continuous disputes and contradictory findings regarding women's intuition and men's rationality (e.g., Epstein, 2003; Hayes et al., 2004; Hodgkinson \& Sadler-Smith, 2003; Lieberman, 2000; Myers Briggs et al., 
1998; Sladek et al., 2010) led us to examine gender differences in PID and REI. In Study 1 , we found that when evaluating their own preferences, women report a preference for more intuitive decision-making (PID) than men, but there were no differences in deliberation. Furthermore, the effect sizes of these differences are small, so they probably reflect culturally internalized stereotypes more than any real difference. Betsch (2004) claims that PID maps affective intuition (reliance on affective cues for decision-making) and some of the items have an explicit emotional formulation (e.g., "I prefer emotional people.", "I like emotional situations, discussions, and movies."), therefore, we think that our results are probably more in line with Ickes's (1997) findings: when relying on self-report methods, women tend to score higher in measures of empathy, but when empathy is tested by performance, differences between men and women in empathy tend to disappear. This would mean that women score higher in intuition not because of their actual higher reliance on intuitive decision-making, but because they conform more to the stereotype of intuitive women. Alternatively, men could also conform to the stereotype of masculinity, which avoids emotional content in discussions and films, and this could result in the significant gender difference in affective intuition measured by PID. The absence of a difference in deliberation could also be explained by deliberation's higher social desirability, and given the testing setting, both men and women may have wanted to appear more deliberative than their typical preference, and thus showed no gender differences.

We found some gender differences in REI, where men evaluated themselves as more rational than women, and women reported to be more experiential than men, which is in line with results of Epstein (2003) and Sladek et al. (2010). However, it is questionable whether gender differences with such small effect sizes may cause any difference between wrong and right judgments and decision-makings in real life. Based on these results, it seems that women and men report their preferences in information processing in line with stereotypes of women's higher emotionality and intuition, and men's higher rationality and logic. However, the extent to which this results from stereotypic roles cannot be determined in this study - our results are limited by the self-reported measures used and we did not include any test of social desirability. It would be more appropriate to examine gender differences in other cognitive tasks that tap into the ability to override Type 1 processes (thus indicating higher deliberation), such as CRT, where some evidence of higher rationality of men were found (Frederick, 2005; Čavojová \& Hanák, 2014). Moreover, Čavojová and Hanák (2014) found that high preference of intuition in women can, in fact, cause their lower performance in some cognitive tasks. These findings concern only results from Study 1; in Study 2 there was a disproportion between men and women (1:7.4), and therefore the absence of gender differences was not surprising.

Our results also suggested that with increasing age, preference for deliberation (PID) and rationality (REI) has a tendency to increase. Sladek et al. (2010) found that with increasing age preference decreased for the experiential system (as a consequence of cognitive maturity), as well as the rational system (as a consequence of the self-report nature of scale). The difference between our and their findings can be explained by differ- 
ences in the samples. In Study $174.8 \%$ of our sample were younger than 32 years and only $7.1 \%$ made up the over 41 -years group and in Study 2 the age of participants ranged from 18 to 26. In contrast, Sladek et al. (2010) had differentiated groups in elder age categories in their study. Moreover, their older sample consisted predominately of participants from helping professions (doctors, nurses, paramedics, etc.), while our sample consisted of administrative workers, managers, self-employed professionals or entrepreneurs (in Study 1) and future teachers (in Study 2), which could explain a different pattern of preference for rationality/intuition. Managers and future teachers could be more motivated to present themselves as "rational" and basing their decisions on deliberation. To decide this issue, further research is needed, with a more diverse sample.

What do Intuition Scales Actually Measure?

Our second aim was to examine a possible underlying factor behind scales measuring intuition. We extracted three factors: 1) decision-making based on affect and holistic processing, 2) decision-making based on creativity and cognitions, and 3) planned, deliberative decision-making. Our analyses lead us to conclude that the scales used differentiate appropriately between intuitive and deliberative cognitive styles, and although each of the scales define intuitive processing in a slightly different way, they probably measure different facets of the same underlying construct.

Affective intuition does not seem to be an essential aspect of intuition, and it is more difficult to put the PID into an overall theoretical framework. On the other hand, REI is based on Need for Cognition and Faith in Intuition scales, which can both be perceived either as facilitating or as inhibiting factors of crystallized rationality in Stanovichs (2011) recent framework. Therefore, in further research we would like to focus on the effect of various cognitive styles as either promoting or inhibiting a rational response in several cognitive tasks that can be seen as measures of so-called fluid rationality (Stanovich, 2011). Rationality subscale of REI also proved to be the best and only predictor of performance on cognitive tasks in our other study (Čavojová \& Hanák, 2014).

Together with several other authors (Glöckner \& Witteman, 2010; Pretz \& Totz, 2007; Pretz et al., 2014), we suggest that it is necessary to distinguish between various types of intuition and choose a scale depending on the study purposes. For example, Pretz et al. (2014) published a comprehensive measure of intuition, distinguishing three types of intuition (holistic, inferential, and affective). Further studies should examine not only the predictive validity of these scales with behavioral measures of intuition within various domains, but also how they are related to real-life outcomes and how the preferred cognitive styles contribute to the rationality of people's choices.

\section{Conclusion}

The main contribution of this present paper is validating two most widely used scales for measuring intuition/deliberation within contemporary dual process approach in Slovak samples. However, our results are not limited to local importance. By employing large samples of participants (860 in Study 1 and 428 in Study 2), our results contribute to a larger understanding of psychometric prop- 
erties of these two scales. We highlighted several problematic issues of both scales, but in general, we supported REI as the most appropriate self-reported measure currently available for research. It is based on the comprehensive theoretical model and it is also comparable to contemporary revisions of the dual-process approaches (Stanovich, 2011). However, further research will need to address the issues of its predictive and ecological validity more, especially by examining whether preference for rational thinking actually yields some real-life outcomes.

Received August 31, 2014

\section{References}

Betsch, C. (2004). Präferenz für Intuition und Deliberation (PID): Inventar zur Erfassung von affekt- und kognitionsbasiertem Entscheiden. Zeitschrift für Differentielle und Diagnostische Psychologie, 25(4), 179-197.

Betsch, C. (2005). Präferenz für Intuition und Deliberation - Messung und Konsequenzen von affekt- und kognitionsbasiertem Entscheiden (p. 146). The Faculty of Behavioural and Cultural Studies.

Betsch, C., \& Iannello, P. (2010).Measuring individual differences in intuitive and deliberative decision-making styles. In A. Glöcknerand, C. Witteman (Eds.), Foundation for tracing intuition: Challenges and Methods (pp. 251-278). Hove and New York: Psychology Press.

Betsch, C., \& Kunz, J. J. (2008). Individual strategy preferences and decisional fit. Journal of Behavioral Decision Making, 21, 532-555.

Björklund, F., \& Bäckström, M. (2008). Individual differences in processing styles: Validity of the Rational-Experiential Inventory. Scandinavian Journal of Psychology, 49(5), 439-46.

Buchtel, E. E., \& Norenzayan, A. (2009), Thinking across cultures: Implications for dual processes. In J. S. B. T. Evans, K. Frankish (Eds.), In two minds. Dual processes and beyond (pp. 217238). Oxford: Oxford University Press.

Cools, E., \& Van den Broeck, H. (2007). Development and validation of the Cognitive Style Indicator. The Journal of Psychology, 141, 359-387.
Čavojová, V., Belovičová, Z., \& Sirota, M. (2011). Mindreading and empathy as predictors of prosocial behavior. Studia Psychologica, 53(4), 351-362.

Čavojová, V., \& Hanák, R. (2014). Assessing fluid rationality and its relation to cognitive styles. In T. Ahram, W. Karwowski and T. Marek (Eds.), Proceedings of the 5th International Conference on Applied Human Factors and Ergonomics AHFE 2014, Kraków, Poland 19-23 July 2014, pp. 142-153.

Epstein, S. (2003). Cognitive-Experiential SelfTheory of Personality. In T. Millon, M. J. Lerner (Eds.), Comprehensive handbook of psychology, Volume 5: Personality and social psychology (pp. 159-184). Hoboken, NJ: Wiley and Sons.

Evans, J. S. B. T., \& Stanovich, K. E. (2013), Dualprocess theories of higher cognition: Advancing the debate. Perspectives on Psychological Science, 8(3), 223-241.

Frederick, S. (2005). Cognitive reflection and decision making. Journal of Economic Perspectives, 19(4), 25-42.

Gigerenzer, G. (2008). Gut feelings: Short cuts to better decision making. London: Penguin Books Ltd.

Gladwell, M. (2005). Blink: The power of thinking without thinking. Museum. Time Warner Book.

Glöckner, A., \& Witteman, C. (2010). Foundation for tracing intuition: Models, findings, categorizations. In A. Glöckner and C. Witteman (Eds.), Foundation for tracing intuition: Challenges and Methods (pp. 1-23). Hove and New York: Psychology Press.

Hayes, J., Allinson, C. W., \& Armstrong, S. J. (2004). Intuition, women managers and gendered stereotypes. Personnel Review, 33(4), 403-417.

Hodgkinson, G. P., \& Sadler-Smith, E. (2003).Complex or unitary? A critique and empirical re-assessment of the Allinson-Hayes Cognitive Style Index. Journal of Occupational and Organizational Psychology, 76(2), 243-268.

Ickes, W. (1997). Empathic accuracy. London: Guilford Press.

Kahneman, D. (2011). Thinking, fast and slow. Macmillan.

Lieberman, M. D. (2000). Intuition: A social cognitive neuroscience approach. Psychological Bulletin, 126(1), 109-137.

Marks, A. D. G., Hine, D. W., Blore, R. L., \& Philips, W. J. (2008). Assessing individual differ- 
ences in adolescents' preference for rational and experiential cognition. Personality and Individual Differences, 44, 42-52.

Myers Briggs, I., McCaulley, M. H., Quenk, N. L., \& Hammer, A. L. (1998). MBTI Manual: A guide to the development and use of the Myers-Briggs type indicator (Third Edit.). Palo Alto: Consulting Psychologist Press.

Myers, D. G. (2002). Intuition: Its powers and perils. New Haven and London: Yale University Press.

Norris, P., Pacini, R., \& Epstein, S. (1998). The Rational-Experiential Inventory, short form. Unpublished inventory. University of Massachusetts at Amherst

Pacini, R., \& Epstein, S. (1999). The relation of rational and experiential information processing styles to personality, basic beliefs, and the ratiobias phenomenon. Journal of Personality and Social Psychology, 76(6), 972-987.

Pretz, J. E., \& Totz, K. S. (2007).Measuring individual differences in affective, heuristic, and holistic intuition. Personality and Individual Differences, 43(5), 1247-1257.

Pretz, J. E., Brookings, J. B., Carlson, L. A., Humbert, T. K., Roy, M., Jones, M., \& Memmert, D. (2014). Development and validation of a new measure of intuition: The types of Intuition Scale. Journal of Behavioral Decision Making, 27, 454467.
Richetin, J., Perugini, M., Adjali, I., \& Hurling, R. (2007). The moderator role of intuitive versus deliberative decision making for the predictive validity of implicit and explicit measures. European Journal of Personality, 21, 529-546.

Sadler-Smith, E. (2008). Inside Intuition (p. 352). London and New York: Routledge.

Sirota, M. (2008). Individuálne rozdiely v racionálnom usudzovaní. Kognitívne parametre a komputačné stratégie v „,bayesovskom “ usudzovaní v úlohách s odlišným ičíselnými reprezentáciami (p. 110). Univerzita Komenského.

Sladek, R. M., Bond, M. J., \& Phillips, P. A. (2010). Age and gender differences in preferences for rational and experiential thinking. Personality and Individual Differences, 49(8), 907-911.

Stanovich, K. E. (2011). Rationality and the reflective mind. New York: Oxford University Press.

Stanovich, K. E., West, R. F. (2000). Individual differences in reasoning: Implications for the rationality debate? The Behavioral and Brain Sciences, 23, 645-726.

Westcott, M. R. (1961). On the measurement of intuitive leaps. Psychological Review, 684(9), 267-274.

Witteman, C., van den Bercken, J., Claes, L., \& Godoy, A. (2009). Assessing rational and intuitive ihinking styles. European Journal of Psychological Assessment, 25(1), 39-47.

\title{
SKÚMANIE VHODNOSTI METÓD NA MERANIE INTUÍCIE (PID A REI) PRE SLOVENSKÚ POPULÁCIU
}

\author{
E. B a 11 ová M i ku šková, R. H a nák, V. Č a vojová
}

Súhrn: Existuje viacero meracích nástrojov, pomocou ktorých možno rozlišovat' medzi dvoma typmi spracovávania informácií - intuitívnym a deliberatívnym. V predkladanej štúdii boli overované dve sebahodnotiace škály, Racionálno - experienciálny inventár (REI) a Škála preferencia $\mathrm{k}$ intuícii a deliberácii (PID) na vzorke 860 dospelých a študentov (Štúdia 1). V Štúdii $2(\mathrm{n}=428)$ bola overovaná 2 -faktorová štruktúra škály REI po tom, ako boli upravené problematické položky identifikované v Štúdii 1. Výsledky poukazujú na dobrú vnútornú konzistenciu oboch dotazníkov a na to, že štruktúra slovenských verzií oboch škál zodpovedala štruktúre originálnych škál. Pomocou faktorovej analýzy boli z oboch škál extrahované 3 faktory rozhodovania: a) rozhodovanie založené na emóciách a celostnom spracovávaní, b) rozhodovanie založené na kreativite a kogníciách a c) plánovanie a deliberatívne rozhodovanie. 


\section{Appendix A}

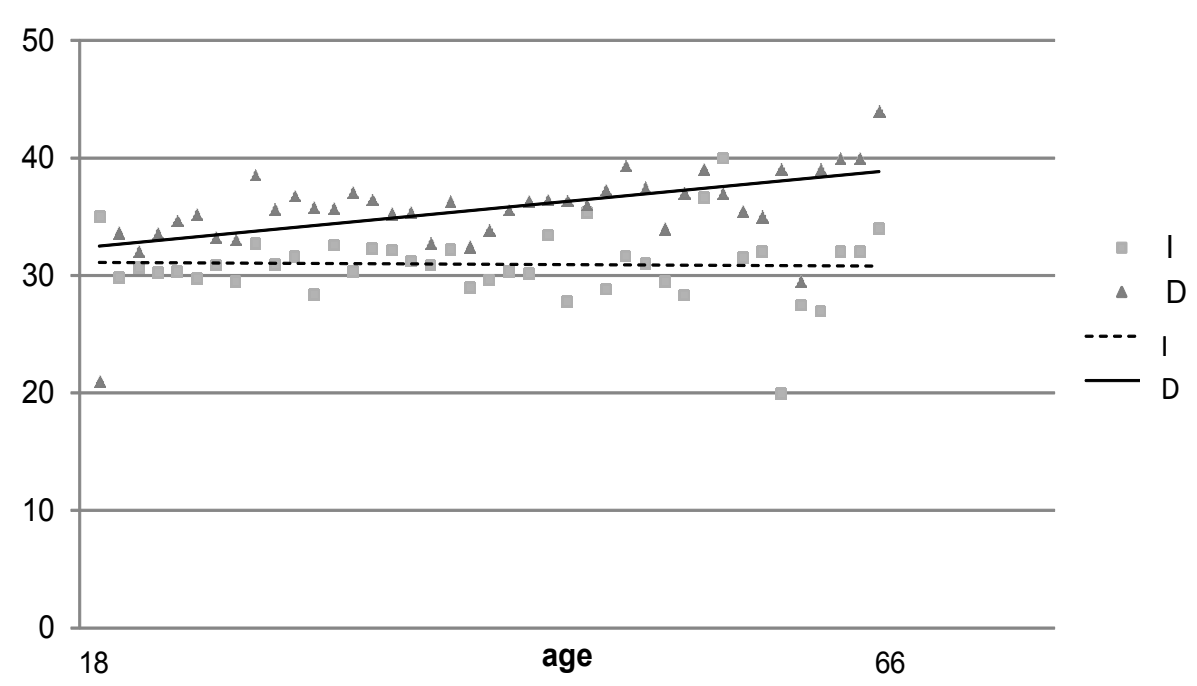

Figure 1 Graphical representations of association between age and preference for intuition and deliberation (PID)

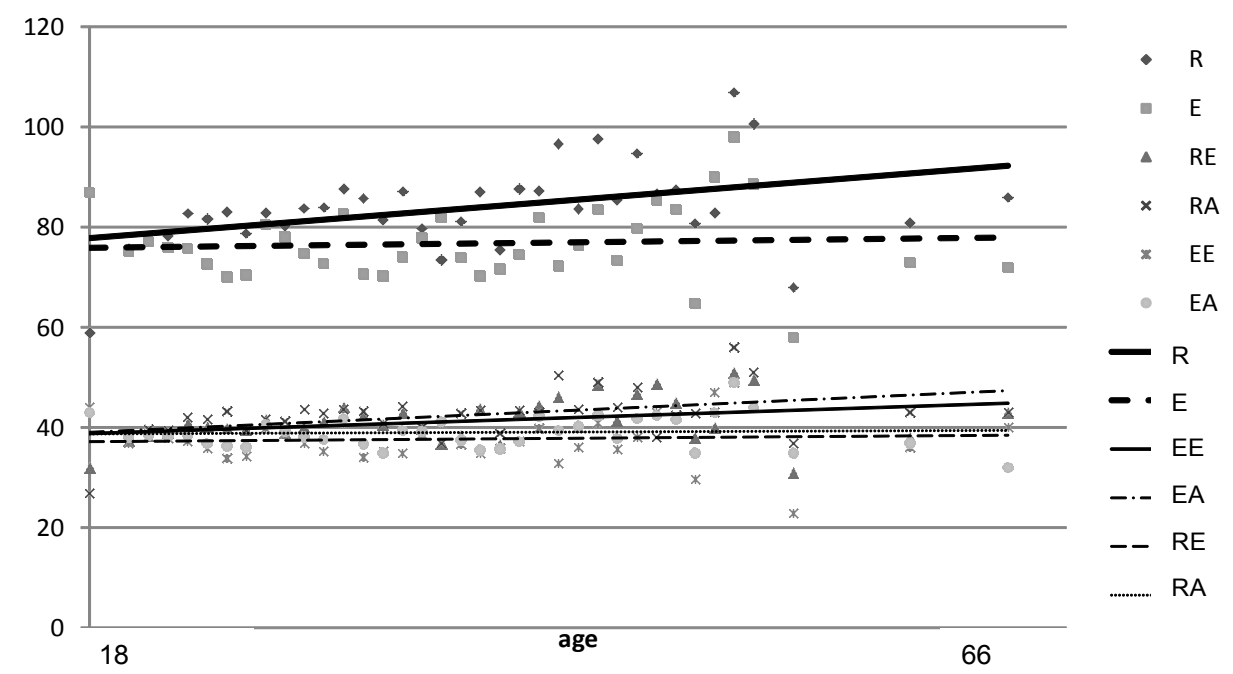

Figure 2 Graphical representations of association between age and rational and experiential thinking (REI, Study 1) 


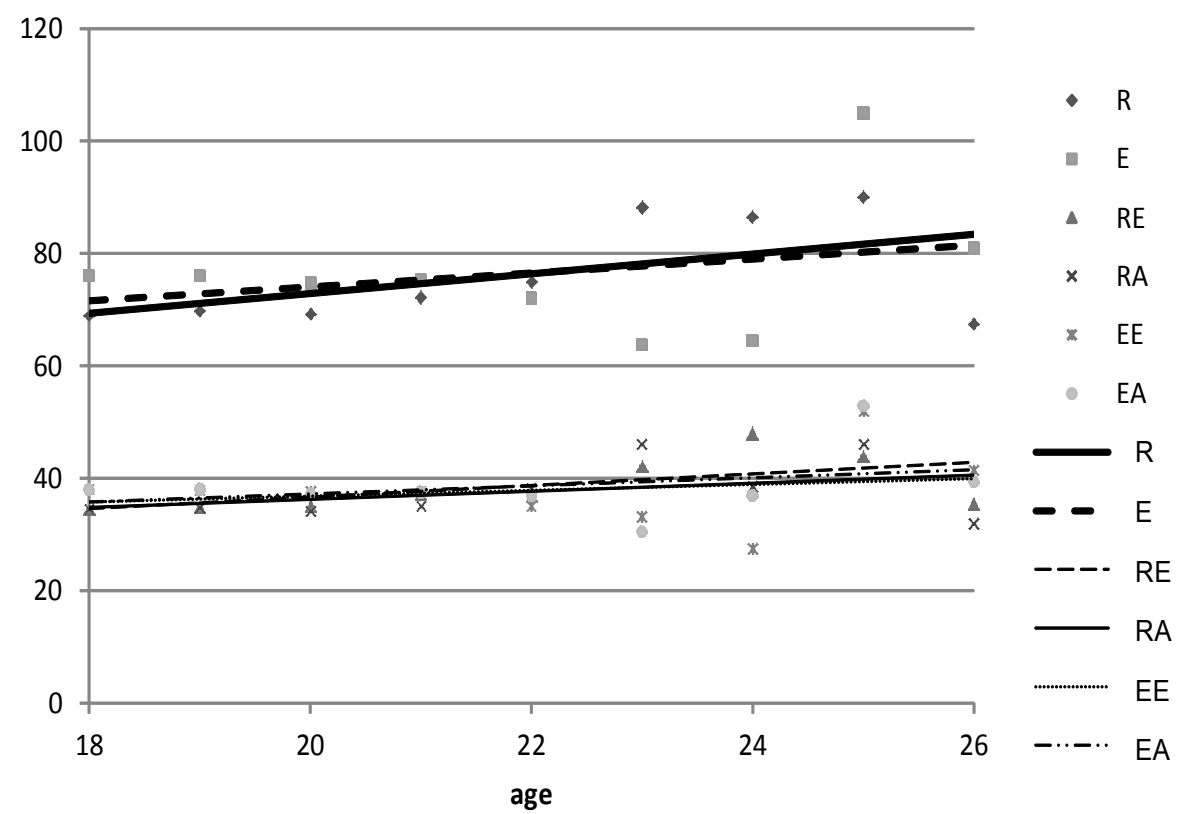

Figure 3 Graphical representations of association between age and rational and experiential thinking (REI, Study 2) 


\section{Appendix B}

Table 1 Factor loadings of REI items for two-factor models (Model 6)

\begin{tabular}{|c|c|c|c|c|c|c|}
\hline item & & factor & estimate & S.E. & $p$ & $\begin{array}{l}\text { St. regression } \\
\text { weights }\end{array}$ \\
\hline REI re1 & $<---$ & & 1 & & & .505 \\
\hline REI_re2 & $<---$ & & .753 & .11 & $* * *$ & .423 \\
\hline REI_re3 & $<---$ & & 1.148 & .138 & $* * *$ & .562 \\
\hline REI_re4 & $<---$ & & 1.056 & .132 & $* * *$ & .530 \\
\hline REI_re5 & $<---$ & & 1.052 & .131 & $* * *$ & .531 \\
\hline REI_re6 & $<---$ & & .648 & .104 & $* * *$ & .37 \\
\hline REI_re7 & $<---$ & & .479 & .113 & $* * *$ & .236 \\
\hline REI_re9 & $<---$ & & .433 & .105 & $* * *$ & .228 \\
\hline REI_re10 & $<---$ & & .447 & .103 & $* * *$ & .242 \\
\hline REI_ra1 & $<---$ & REI-R & 1.082 & .13 & $* * *$ & .565 \\
\hline REI_ra2 & $<---$ & & 1.205 & .137 & $* * *$ & .617 \\
\hline REI_ra3 & $<---$ & & 1.27 & .139 & $* * *$ & .667 \\
\hline REI_ra4 & $<---$ & & .991 & .123 & $* * *$ & .53 \\
\hline REI_ra5 & $<---$ & & .348 & .111 & .002 & .171 \\
\hline REI_ra6 & $<---$ & & .795 & .111 & $* * *$ & .448 \\
\hline REI_ra7 & $<---$ & & .973 & .124 & $* * *$ & .514 \\
\hline REI_ra8 & $<---$ & & .467 & .098 & $* * *$ & .269 \\
\hline REI_ra9 & $<---$ & & .845 & .114 & $* * *$ & .469 \\
\hline REI_ra10 & $<---$ & & .431 & .096 & $* * *$ & .25 \\
\hline REI_ee1 & $<---$ & & 1 & & & .674 \\
\hline REI_ee2 & $<---$ & & 1.05 & .085 & $* * *$ & .673 \\
\hline REI_ee3 & $<---$ & & 1.192 & .088 & $* * *$ & .755 \\
\hline REI_ee4 & $<---$ & & .758 & .089 & $* * *$ & .453 \\
\hline REI_ee5 & $<---$ & & 1.035 & .083 & $* * *$ & .686 \\
\hline REI_ee6 & $<---$ & & .275 & .092 & .003 & .154 \\
\hline REI_ee7 & $<---$ & & .491 & .088 & $* * *$ & .29 \\
\hline REI_ee8 & $<---$ & & .437 & .084 & $* * *$ & .271 \\
\hline REI_ee10 & $<---$ & REI-E & .591 & .09 & $* * *$ & .344 \\
\hline REI_ea1 & $<---$ & & .634 & .079 & $* * *$ & .424 \\
\hline REI_ea2 & $<---$ & & .66 & .09 & $* * *$ & .383 \\
\hline REI_ea3 & $<---$ & & 1.139 & .084 & $* * *$ & .757 \\
\hline REI_ea4 & $<---$ & & .533 & .095 & $* * *$ & .294 \\
\hline REI_ea5 & $<---$ & & .933 & .093 & $* * *$ & .539 \\
\hline REI_ea6 & $<---$ & & .573 & .087 & $* * *$ & .345 \\
\hline REI_ea7 & $<---$ & & .892 & .082 & $* * *$ & .585 \\
\hline REI_ea9 & $<---$ & & .607 & .082 & $* * *$ & .387 \\
\hline
\end{tabular}


STUDIA PSYCHOLOGICA, 57, 2015, 1

Table 2 Factor loadings of REI items for four-factor models (Model 7)

\begin{tabular}{|c|c|c|c|c|c|c|}
\hline item & & factor & estimate & S.E. & $p$ & $\begin{array}{l}\text { St. regression } \\
\text { weights }\end{array}$ \\
\hline REI rel & $<---$ & \multirow{9}{*}{ REI-RE } & 1 & & & .526 \\
\hline REI_re2 & $<---$ & & .751 & .108 & $* * *$ & .439 \\
\hline REI_re3 & $<---$ & & 1.203 & .14 & $* * *$ & .613 \\
\hline REI_re4 & $<---$ & & 1.083 & .132 & $* * *$ & .566 \\
\hline REI_re5 & $<---$ & & 1.4 & .129 & $* * *$ & .547 \\
\hline REI_re6 & $<---$ & & .678 & .104 & $* * *$ & .404 \\
\hline REI_re7 & $<---$ & & .527 & .113 & $* * *$ & .27 \\
\hline REI_re9 & $<---$ & & .41 & .104 & $* * *$ & .225 \\
\hline REI_re10 & $<---$ & & .496 & .103 & $* * *$ & .279 \\
\hline REI_ral & $<---$ & \multirow{10}{*}{ REI-RA } & 2.241 & .462 & $* * *$ & .549 \\
\hline REI_ra2 & $<---$ & & 2.653 & .532 & $* * *$ & .637 \\
\hline REI_ra3 & $<---$ & & 2.725 & .542 & $* * *$ & .671 \\
\hline REI_ra4 & $<---$ & & 2.092 & .436 & $* * *$ & .525 \\
\hline REI_ra5 & $<---$ & & .647 & .26 & .013 & .149 \\
\hline REI_ra6 & $<---$ & & 1.855 & .393 & $* * *$ & .49 \\
\hline REI_ra7 & $<---$ & & 2.272 & .466 & $* * *$ & .563 \\
\hline REI_ra8 & $<---$ & & .986 & .267 & $* * *$ & .266 \\
\hline REI_ra9 & $<---$ & & 1.974 & .414 & $* * *$ & .513 \\
\hline REI_ra10 & $<---$ & & 1 & & & .272 \\
\hline REI_ee1 & $<---$ & \multirow{9}{*}{ REI-EE } & 1 & & & .686 \\
\hline REI_ee2 & $<---$ & & 1.059 & .084 & $* * *$ & .69 \\
\hline REI_ee3 & $<---$ & & 1.185 & .086 & $* * *$ & .764 \\
\hline REI_ee4 & $<---$ & & .727 & .087 & $* * *$ & .442 \\
\hline REI_ee5 & $<---$ & & 1.024 & .081 & $* * *$ & .69 \\
\hline REI_ee6 & $<---$ & & .255 & .091 & .005 & .146 \\
\hline REI_ee7 & $<---$ & & .473 & .087 & $* * *$ & .285 \\
\hline REI_ee8 & $<---$ & & .429 & .083 & $* * *$ & .271 \\
\hline REI_ee10 & $<---$ & & .6 & .088 & $* * *$ & .356 \\
\hline REI_ea1 & $<---$ & \multirow{8}{*}{ REI-EA } & 1 & & & .453 \\
\hline REI_ea2 & $<---$ & & .986 & .159 & $* * *$ & .388 \\
\hline REI_ea3 & $<---$ & & 1.709 & .193 & $* * *$ & .77 \\
\hline REI_ea4 & $<---$ & & .792 & .157 & $* * *$ & .296 \\
\hline REI_ea5 & $<---$ & & 1.368 & .181 & $* * *$ & .536 \\
\hline REI_ea6 & $<---$ & & .877 & .15 & $* * *$ & .358 \\
\hline REI_ea7 & $<---$ & & 1.366 & .17 & $* * *$ & .607 \\
\hline REI_ea9 & $<---$ & & 1 & & & \\
\hline
\end{tabular}

